\title{
Sodium-Dependent Dopamine Transporter
}

National Cancer Institute

\section{Source}

National Cancer Institute. Sodium-Dependent Dopamine Transporter. NCI Thesaurus. Code C113530.

Sodium-dependent dopamine transporter (620 aa, $\sim 68 \mathrm{kDa}$ ) is encoded by the human SLC6A3 gene. This protein plays a role in the downregulation of dopamine signaling. 